\title{
Yet another carnivorous semi-slug found in Belgium: Daudebardia rufa (Draparnaud, 1805) (Gastropoda: Oxychilidae)
}

\author{
Louis Bronne ${ }^{1, *}$, Johann Delcourt ${ }^{2,3} \&$ Tom Van den Neucker ${ }^{4,5}$ \\ ${ }^{1}$ Natagora (NPO), Traverse des Muses 1, 5000 Namur, Belgium. \\ ${ }^{2}$ University of Liège, Department of Biology, Ecology and Evolution, Service of Behavioural Biology, \\ Institut de Zoologie (I1), Quai Van Beneden 22, 4020 Liège, Belgium. \\ ${ }^{3}$ University of Liège, High Fens Scientific Station (SSHF), rue de Botrange 137, \\ 4950 Robertville, Belgium. \\ ${ }^{4}$ University of Antwerp, Department of Biology, Ecosystem Management Research Group, \\ Universiteitsplein 1C, 2160 Wilrijk, Belgium. \\ ${ }^{5}$ Biodiversity Inventory for Conservation NPO (BINCO), Walmersumstraat 44, \\ 3380 Glabbeek, Belgium. \\ *Corresponding author: louis.bronne@natagora.be
}

Keywords. Daudebardia rufa, Daudebardia brevipes, distribution, first record, Belgium, snail, semislug.

Bronne L., Delcourt J. \& Van den Neucker T. (2021). Yet another carnivorous semi-slug found in Belgium: Daudebardia rufa (Draparnaud, 1805) (Gastropoda: Oxychilidae). Belgian Journal of Zoology 151: 99-105. https://doi.org/10.26496/bjz.2021.88

This note reports the first record of the semi-slug Daudebardia rufa (Draparnaud, 1805) in Belgium and adds a new record of $D$. brevipes (Draparnaud, 1805). After the first report of $D$. brevipes in Belgium (Trooz, May 2020) [1], ten surveys were conducted at random natural or semi-natural locations along the river Vesdre, in order to assess to what extent the species was established. The surveys were carried out between September and December 2020. On December $20^{\text {th }} 2020$, the first author found two fresh empty shells of $D$. rufa on cobblestones at the bottom of a railway bridge embankment, situated between the Vesdre and a road in Ensival $\left(50.5742^{\circ} \mathrm{N}, 5.8310^{\circ} \mathrm{E}\right)$, a village in the centre of the Province of Liège, Belgium (Fig. 1). Two days later, on December $22^{\text {nd }} 2020$, the second author found a living adult on the embankment wall at the opposite entrance of the bridge. On December $25^{\text {th }} 2020$, a fresh dead adult specimen was found. Another one was found on January $29^{\text {th }} 2021$, along with a live juvenile and an empty shell. An empty shell of $D$. brevipes was also collected at the same locality.

The site is located at the crossing between the left riverbank of the Vesdre valley (142 $\mathrm{m}$ above sea level) and a railway bridge, around a small tunnel. The soil consists of recent alluvial deposits of clay and sand. The bedrock is characterized by Devonian shales and dolomitic limestones. The bridge and its embankments are made of limestone. The slopes of these embankments are poorly consolidated, allowing the development of mosses, herbs, ferns, trees and shrubs, particularly on the northern side. Trees and 


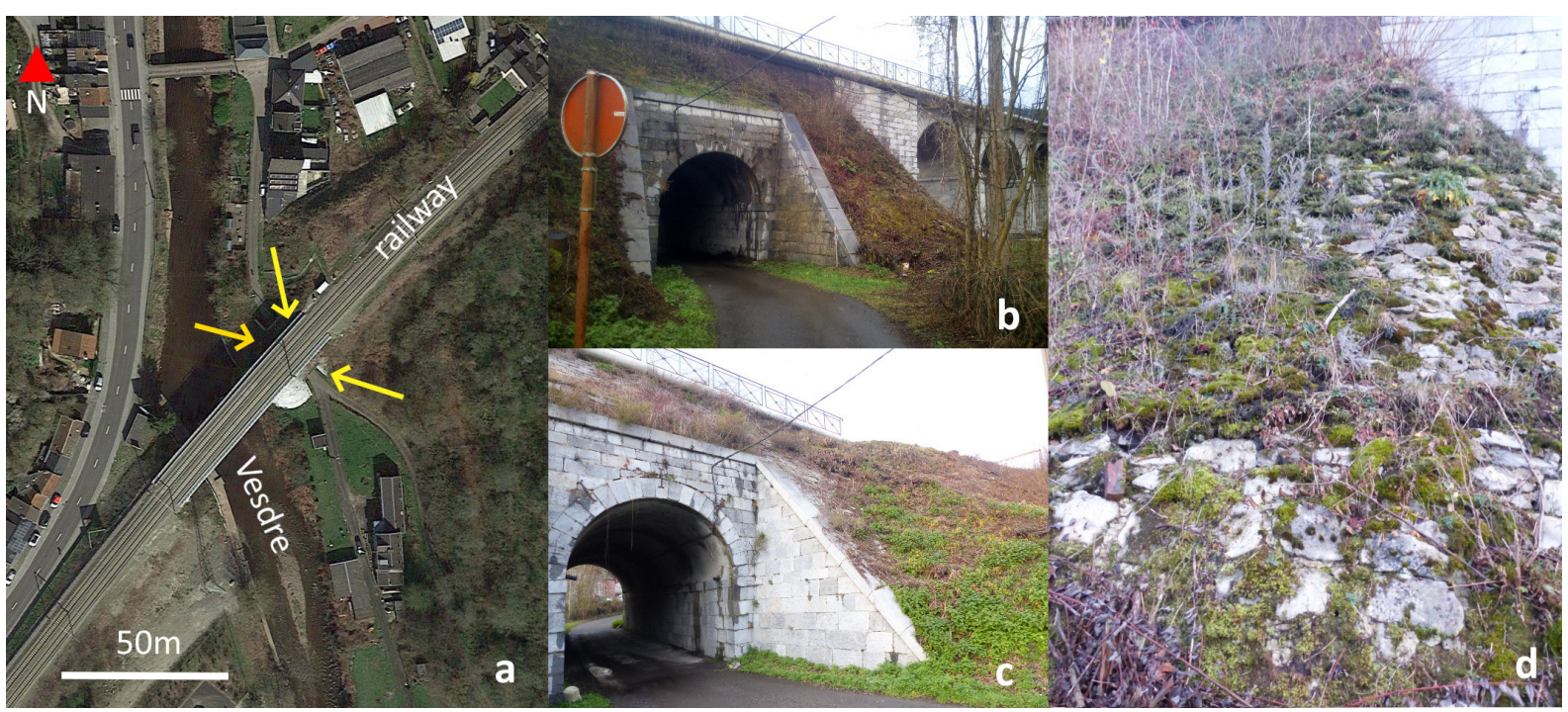

Fig. 1 - Site description: (a) Orthoview (scale bar $=50 \mathrm{~m}$, the yellow arrows indicate where the specimens of D. rufa were found) [2]; (b) view of the northern side of the tunnel; (c) view of the southern side of the tunnel; (d) details of the stony slopes of the railway embankment. Pictures taken in December 2020 and January 2021.

shrubs had been cut in 2019, with the resulting wood chips scattered on the railway embankment, mainly at the NE of the tunnel. The riparian vegetation (including Rubus sp., Fallopia japonica and Urtica dioica) along the Vesdre had also been recently cut. Deduced from historical maps and image archives from [2][3][4], at least three cycles of maintenance and cutting were carried out over the last 20 years. Vegetation on the NW railway embankment, where most specimens were found, is dominated by Salix caprea, Corylus avellana, Rubus sp., Asplenium trichomanes, Dryopteris sp. and mosses. The NE embankment displays the same shrub assemblage, with the addition of Acer pseudoplatanus. The SW embankment is dryer and more sun-exposed, with very little vegetation. Corylus avellana, Sambucus nigra, Crataegus monogyna, Rubus sp., Rosa canina, Senecio inaequidens and Urtica dioica are the main species on the SE embankment, where two specimens of D. rufa were found. The woodland located at the SE is dominated by C. avellana and Quercus robur.

The empty shells and the live adult-sized specimen of D. rufa collected in Ensival (Fig. 2) fit the description of the species and differ from the closely related $D$. brevipes [5][6][7]. The stretched body length of the adult D. rufa measured $16 \mathrm{~mm}$ and its shell width measured $4.5 \mathrm{~mm}$. The last whorl of the adult shell is strongly ear-shaped and the upper and lower parts of the shell mouth are almost parallel, so that the shell appears oblong. The coiled part of the shell occupies 40 to $50 \%$ of the total width; in comparison, $D$. brevipes has a concave shell outline and the coiled part occupies only 30 to $40 \%$ of its total width [5][6][7]. There are no significant anatomical differences between D. rufa and D. brevipes [5].

Daudebardia rufa is found in parts of Central and Southern Europe (Fig. 3), the Ukraine, Turkey and Algeria [6][7]. Recently, D. rufa was also found in Western Europe, including the Netherlands [8] and UK [9]. Fossil records of D. rufa dated to the Eemian interglacial period (circa 130-115kyr BP) from the Somme region in France [10] suggest that its range reached further westward than known at present, apart from the recent find in the UK [9]. Daudebardia rufa is found in humid deciduous highland and montane forests, typically between 300 and $1500 \mathrm{~m}$ elevation, often near water [6][7][11]. In Central 

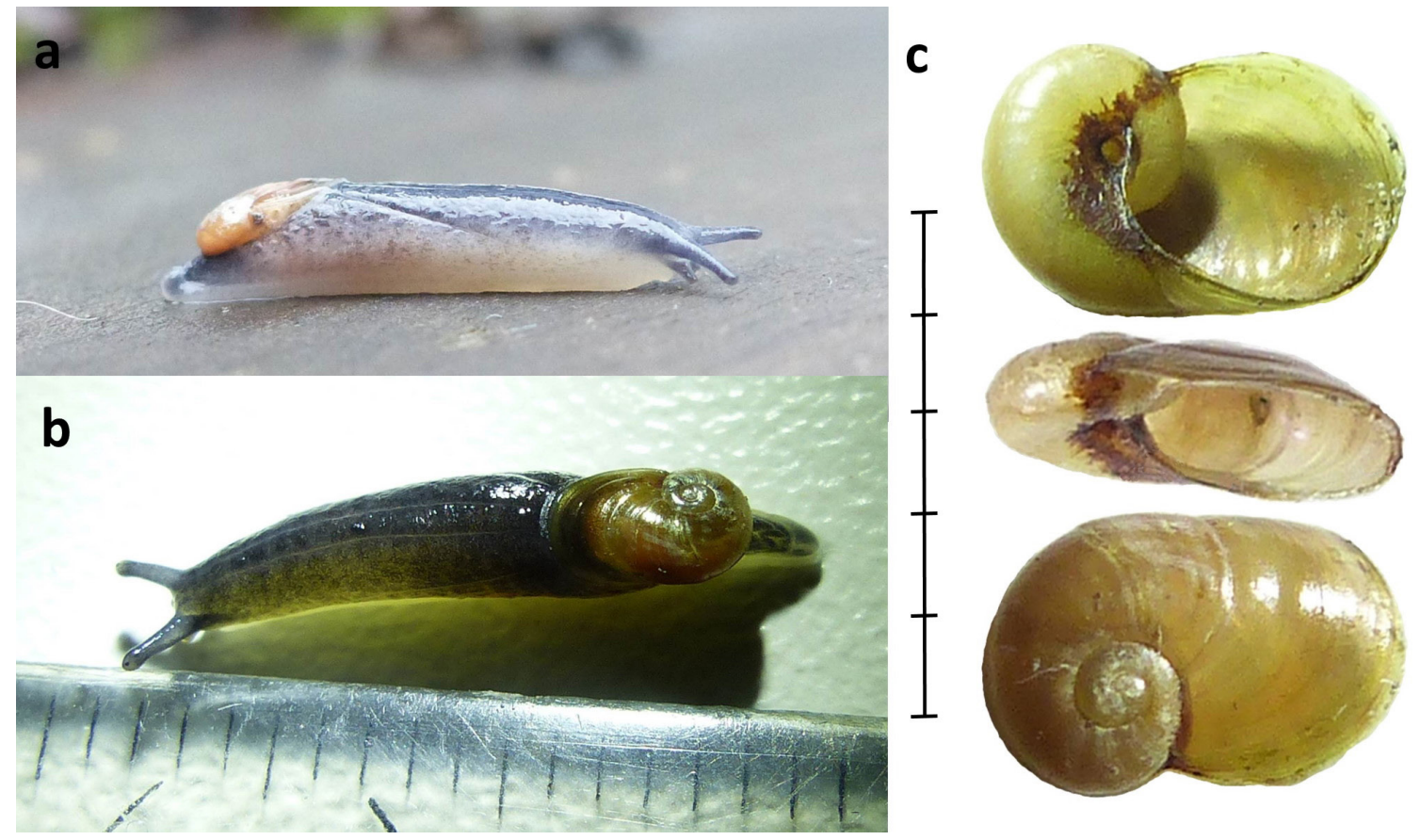

Fig. 2 - The live adult specimen of Daudebardia rufa found in Ensival (a-b) and its shell (c). Scale bar is in $\mathrm{mm}$.

Europe, D. rufa has been reported from Fagus, Fraxinus, Quercus, Carpinus and Salix forests [11][12] [13][14], as well as from scrublands and grasslands on mountain slopes [13]. In southern regions, it has been recorded in Fagus forests, sparse Quercus and Fraxinus forests and ravine forest fragments with Acer pseudoplatanus [15][16][17]. Like D. brevipes, D. rufa is mesohygrophilic and cold-resistant [18]. The species does not tolerate warm and dry conditions, and is therefore mostly subterranean, living in deep, loose soil. Acidic soils are avoided [6][7][11]. During cooler periods, in spring, late autumn, and on mild winter days, D. rufa can be found under stones, moss, leaf litter and decaying wood [11]. Daudebardia rufa is carnivorous and mainly feeds upon molluscs, earthworms, isopods and insect larvae [6][7][11].

Daudebardia rufa is a rare species, although it is more common and widespread than D. brevipes [7] (Fig. 3). The conservation status of D. rufa differs regionally. In Germany, D. rufa is categorized as endangered [19]; in the Czech Republic, as near threatened [20]; in Switzerland, as vulnerable [11]; and in Austria, as of least concern [21]. At the western edge of its range (Fig. 3), the presence of D. rufa has been established for a long time in Luxembourg [22] as well as in France and Germany along the Rhine valley [23][24]. Remarkably, both $D$. rufa and D. brevipes have recently been reported from several new localities in Western Europe (Fig. 3). In 2016, a population of D. rufa was found in Wales (UK) [9]. In 2017, fresh shells of D. rufa and D. brevipes were found together in the western part of the German Eifel, at two different sites in the Urft valley (Pardey, pers. comm.), and a live juvenile of D. rufa south of Aachen (Majoor, pers. comm.). In 2019, a single specimen of D. brevipes was found in a greenhouse in Ghent, Belgium [25]. In May 2020, live specimens of D. brevipes were found in a natural environment in Belgium, along the Vesdre [1]. Finally, in November 2020, empty shells and live specimens of both species were found in the valley of the Eyserbeek in the Netherlands [8]. Interestingly, the rivers Urft 


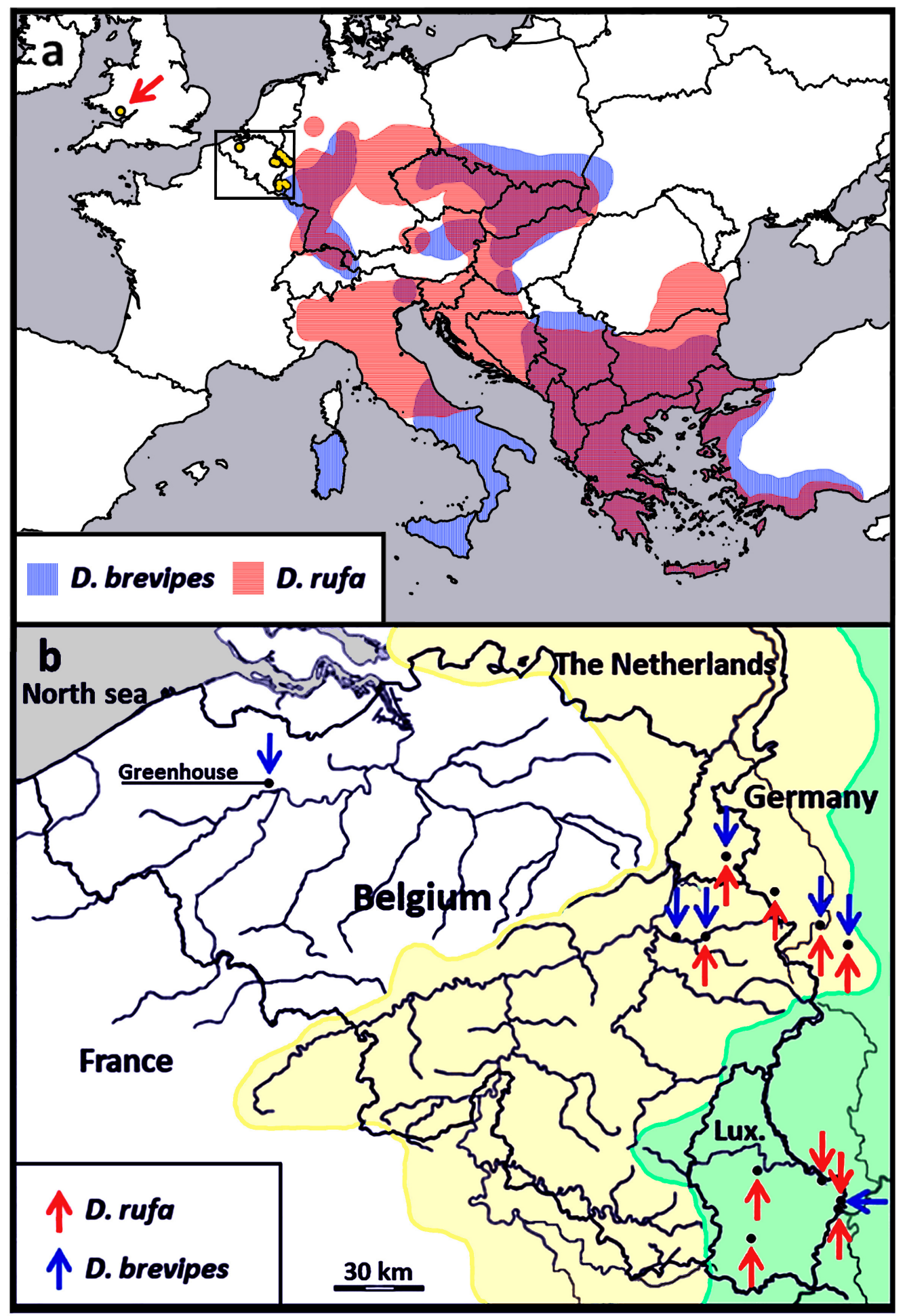

Fig. 3 - (a) Range map of Daudebardia rufa and D. brevipes in Europe, redrawn from WeLTERSCHULTES [7]. Yellow dots indicate recently reported localities along the western part of their ranges. The locality of D. rufa in the UK [9] is indicated by the red arrow. (b) Reported records of Daudebardia from Benelux and adjacent localities in Germany are indicated in the cut-out below, corresponding with the black rectangle in the top panel (a). The Meuse and Rhine basins are indicated in pale yellow and pale green, respectively. Black dots on the bottom panel (b) indicate published and unpublished records (see text) and records available from the GBIF portal [28]. 
in Germany, Vesdre in Belgium and Eyserbeek in the Netherlands, all belong to the Meuse basin. This suggests that $D$. rufa and $D$. brevipes are firmly established along the Meuse basin, despite the Rhine basin long being considered as the westernmost range limit of both species (Fig. 3).

The recently established presence of both Daudebardia species in the Meuse basin could be the result of a westward range expansion. However, BRONNE \& VAN DEN NEUCKER [1] hypothesised that the D. brevipes population along the Vesdre in Trooz may have been previously overlooked, based on the relatively pristine habitat. This may also be the case for $D$. rufa, although the site at Ensival is clearly more disturbed than the site at Trooz, and it therefore cannot be ruled out that $D$. rufa was introduced. Likewise, OwEN et al. [9] expressed uncertainty about whether D. rufa is an overlooked native species or a species recently introduced in Wales (UK). The find of D. rufa along the Vesdre in Ensival resulted from surveys carried out after the earlier find of D. brevipes in Trooz. Similarly, the find of D. brevipes in the Netherlands along the Eyserbeek was the result of targeted searches after the previous find of $D$. rufa, which was first reported on a data portal for citizen scientists [8]. Online data portals such as iNaturalist and Waarnemingen.be/Observations.be are valuable early warning systems to detect upcoming invasive species [26], but could also play an important role in monitoring neonative species (i.e., species that have expanded their range as a response to human-induced environmental changes [27]) and in detecting previously overlooked native species.

Although it is not clear whether D. rufa and D. brevipes were introduced or should be considered (neo)native, our study shows that both species are firmly established in the Meuse basin. The presence of juvenile specimens of $D$. rufa indicates that the Belgian population is self-sustaining. The rapid communication of the first Belgian records of D. rufa and D. brevipes and the overview of the current distribution of both species in Western Europe (Fig. 3) could serve as a baseline for further monitoring the newly recorded populations. Given that D. rufa and D. brevipes may be (neo)native in Belgium and given their general rarity in Europe, protective measures should be considered for both species, although the uncertainty regarding the origins of the Belgian Daudebardia populations should be taken into account. Such measures may include protection of their preferred habitat, in particular deciduous forests with deep soils in the vicinity of small rivers [6][7][11].

\section{Acknowledgements}

Three of the surveys along the Vesdre were conducted by Kurt Boux and Yolan Bosteels. Étienne Meuleman and the Royal Belgian Society of Malacology (SRBM), as well as Alain Bertrand helped with the compilation of the bibliography. Caroline Orban and Martijn Van Roie proofread the text. Two anonymous reviewers and the editor are thanked for improving the manuscript.

\section{References}

[1] Bronne L. \& VAN DEN Neucker T. (2020). The carnivorous semi-slug Daudebardia brevipes (Gastropoda: Oxychilidae) in Belgium: an overlooked native species? Belgian Journal of Zoology 150: 197-202. https://doi.org/10.26496/bjz.2020.81

[2] Google (s.d.) Map of Wegnez-Ensival, Belgium [map]. Google Earth 2005, 2007, 2009, 2015, 2016, 2021. Google, Aerodata International Surveys, Maxar Technologies, \& Geobasis-DE/BKG. Available from https://earth.google.com [accessed 26 August 2021].

[3] Google (s.d.) Rue du Purgatoire, Ensival, Belgium. Google Street View 2009-2013-2017-2020. Available from https://google.com/maps [accessed 30 December 2020].

[4] Service Public de Wallonie (s.d.) Orthophotos 2001-3, 2006-7, 2009-10, 2012-13, 2015, 2016, 2018, 2019, 2020 [map]. Available from https://geoportail.wallonie.be [accessed 30 December 2020]. 
[5] Riedel A. (1967). Daudebardiinae (Gastropoda, Zonitidae) Bulgariens. Annales Zoologici 24: 463483.

[6] Kerney M.P. \& Cameron R.A.D. (1979). A Field Guide to the Land Snails of Britain and NorthWest Europe. Collins, London.

[7] Welter-Schultes F.W. (2012). European Non-Marine Molluscs, a Guide for Species Identification. Planet Poster Editions, Göttingen.

[8] Tempelman D. (2021). Nieuw in Nederland: de semi-naaktslak Daudebardia rufa (Draparnaud, 1805). Spirula 426: 35-36.

[9] OWEn C., Rowson B. \& WiLKInSON K. (2016). First record of the predatory semi-slug Daudebardia rufa (Draparnaud, 1805) from the UK (Eupulmonata: Daudebardiidae). Journal of Conchology 42: 119121.

[10] Antoine P., Limondin-Lozouet N., Auguste P., Locht J.-L., Galheb B., Reyss J.-L., Escudé É., CARbonel P., Mercier N., BAhain J.-J., FAlguères C. \& Voinchet P. (2006). Le tuf de Caours (Somme, France): mise en évidence d'une séquence eemienne et d'un site paléolithique associé. Quaternaire 17 (4): 281-320. https://doi.org/10.4000/quaternaire.880

[11] Boschi C. (2011). Die Schneckenfauna der Schweiz. Ein umfassendes Bild- und Bestimmungsbuch. Haupt, Bern/Stuttgart/Wien.

[12] Sólymos P., Gaudényi T., Deli T. \& NAgy A. (2004). Data on the land snail fauna of the Fruska Gora Mountain (Serbia) with some biogeographical remarks. Malacological Newsletter 22: 149-153.

[13] GeORGIEV D.G. (2005). Species diversity and habitat distribution of the Malacofauna (Mollusca: Bivalvia, Gastropoda) of Surnena Sredna Gora Mountain (Southern Bulgaria). In: GRUEV B., Nikolova M. \& Donev A. (eds) Proceedings of the Balkan Scientific Conference of Biology in Plovdiv (Bulgaria) from $19^{\text {th }}$ till $21^{\text {st }}$ of May 2005: 428-435.

[14] ČILIAK M. \& ŠTEFFeK J. (2011). Preliminary malacological survey of the site of community importance Kamenná Baba (Branisko-Bachureň). Folia faunistica Slovaca 16: 85-89.

[15] Sólymos P. (2000). Data on the recent mollusc fauna of the western part of the Villány Hills, S Hungary. Malacological Newsletter 18: 105-108.

[16] Ferreri D., Bodon M. \& Manganelli G. (2005). Molluschi terrestri della provincia di Lecce. Thalassia Salentina 28: 31-130. https://doi.org/10.1285/i15910725v28p31

[17] Hallgass A. \& VAnnozzi A. (2016). Terrestrial gastropods (Mollusca Gastropoda) from Lepini Mountains (Latium, Italy): a first contribution. Biodiversity Journal 7: 93-102.

[18] IRIKOV A. \& Mollov I. (2015). Terrestrial gastropods (Mollusca, Gastropoda) of Strandzha Mountain and the Black Sea coast (Bulgaria and Turkey). Historia naturalis bulgarica 21: 13-48. https://doi.org/10.13140/RG.2.1.3908.0809

[19] Hackenberg E. \& MÜLler R. (2017). Rote Liste und Gesamtartenliste der Weichtiere (Mollusca: Gas-tropoda und Bivalvia) von Berlin. In: Der Landesbeauftragte für Naturschutz und Landschaftspflege / Senatsverwaltung für Umwelt, Verkehr und Klimaschutz (Hrsg.) Rote Listen der gefährdeten Pflanzen, Pilze und Tiere von Berlin. https://doi.org/10.14279/depositonce-5845

[20] JUŘIČKOVÁ L. \& KUČERA T. (2005). Ruins of medieval castles as refuges for endangered species of molluscs. Journal of Molluscan Studies 71: 233-246. https://doi.org/10.1093/mollus/eyi031

[21] ReISChÜTZ A. \& ReISchÜTZ P.L. (2007). Rote Liste der Weichtiere (Mollusca) Österreichs. In: ZulKa K.P. (red.) Rote Listen gefährdeter Tiere Österreichs. Teil 2: Kriechtiere, Lurche, Fische, Nachtfalter, Weichtiere: 363-433. Grüne Reihe des Lebensministeriums 14/2. 
[22] Ferrant V. (1892). Beiträge zur Molluskenfauna des Grossherzogtums Luxemburg (Schluss). Bulletin de la Société des naturalistes luxembourgeois 2: 21-26.

[23] Germain F. (1930). Mollusques terrestres et fluviatiles (1ère partie). Faune de France 21: 1-477.

[24] Bichain J.M. (2016). Description et répartition des escargots terrestres du Haut- et du Bas-Rhin. Malacofaune d'Alsace Vol. 1. Available from

http://www.odonat-grandest.fr/telechargements/FauneAlsace/CahiersTechniquesMalaco/malacofaune v1_2016.pdf [accessed 25 January 2021].

[25] VAn DEN Neucker T. \& Soors J. (2019). The carnivorous semi-slug Daudebardia brevipes, a remarkable new greenhouse snail in the botanical garden of Ghent (Belgium) (Gastropoda, Oxychilidae). Spixiana 42: 192.

[26] Swinnen K.R.R., Vercayie D., Vanreusel W., Barendse R., Boers K., Bogaert J., Dekeukeleire D., Driessens G., Dupriez P., Jooris R., Steeman R., Van Asten K., Van Den Neucker T., Van Dorsselaer P., Van Vooren P., Wysmantel N., Gielen K., Desmet P., HERREMANS M., all working groups, species validators and recorders (2018). Waarnemingen.be - Nonnative plant and animal occurrences in Flanders and the Brussels Capital Region, Belgium. BioInvasions Records 7: 335-342. https://doi.org/10.3391/BIR.2018.7.3.17

[27] Essl F., Dullinger S., Genovesi P., Hulme E.P., JeschKe J.M., Katsanevakis S., KÜHN I., LENZner B., PAUChard A., PYŠEK P., RABITSCH W., Richardson D.M., Seebens H., Van Kleunen M., Van Der Putten W.H., Vilà M. \& Bacher S. (2019). A conceptual framework for range-expanding species that track human-induced environmental change. BioScience 69: 908-919. https://doi.org/10.1093/biosci/biz101

[28] GBIF.ORG (24 February 2021). GBIF Occurrence Download. https://doi.org/10.15468/d1.4a7xq5

Manuscript received: 8 March 2021

Manuscript accepted: 1 September 2021

Published on: 13 September 2021

Branch editor: Kurt Jordaens 